\title{
Clinical and laboratory findings in sheep experimentally poisoned by Palicourea marcgravii and the use of magnesium chloride with possible therapeutic effect on poisoning ${ }^{1}$
}

\author{
Isabelle M. Cunha ${ }^{2 *}$ (D), Daniel A.B. Lessa ${ }^{3}$, Vivian A.N. Carvalho ${ }^{3}$, Nayro X. Alencar ${ }^{3}$, \\ André L.S. Teixeira ${ }^{2}$, Saulo A. Caldas ${ }^{4}$, Guilherme N. Souza ${ }^{3}$ \\ and Michel J.SA. Helayel ${ }^{3}$
}

\begin{abstract}
Cunha I.M., Lessa D.A.B., Carvalho V.A.N., Alencar N.X., Teixeira A.L.S., Caldas S.A., Souza G.N. \& Helayel M.J.SA. 2021. Clinical and laboratory findings in sheep experimentally poisoned by Palicourea marcgravii and the use of magnesium chloride with possible therapeutic effect on poisoning. Pesquisa Veterinária Brasileira 41:e06931, 2021. Universidade Federal Fluminense, Av. Almirante Ary Parreiras 503, Santa Rosa, Niterói, RJ 24230-340, Brazil. E-mail: isabellemedvet@gmail.com

This study aimed to examine the efficacy of magnesium chloride therapy in sheep experimentally poisoned by Palicourea marcgravii and describe the clinical and laboratory findings that may aid in early ante mortem diagnosis of this poisoning. P. marcgravii is an important plant within a group of 22 species in Brazil that cause "sudden death." Its toxic component is sodium monofluoroacetate. It was observed that a time for evolution of poisoning was longer in our study compared to other studies that used the same dose of $P$. marcgravii in sheep. However, all animals that were poisoned and subsequently treated with magnesium chloride died. The sheep presented characteristic clinical signs before death in addition to other signs that have not been previously described for this type of poisoning, such as abdominal breathing, coughing, head pressing, and nystagmus. This is the first evaluation of hematological parameters of sheep poisoned by P. marcgravii. Leukocytosis with neutrophilia, hyperfibrinogenemia, and hyperglycemia, associated with hypophosphatemia and elevated levels of serum aspartato aminotransferase (AST), glutamate dehydrogenase (GLDH), urea, creatinine, creatine kinase (CK) and lactate dehydrogenase (LDH), were observed. Additionally, changes were noted in necropsy, such as engorged jugular, large vessel congestion, pulmonary edema. Histological examination revealed vacuolar hydropic degeneration in the distal twisted uriniferous tubules in the kidneys, similar to those reported in previous studies on P. marcgravii poisoning.
\end{abstract}

INDEX TERMS: Treatment, sheep, poisoning, Palicourea marcgravii, magnesium chloride, diagnosis, serum biochemistry, toxic plants.

\footnotetext{
${ }^{1}$ Received on June 4, 2021.

Accepted for publication on July 12, 2021.

${ }^{2}$ Doctoral student, Graduate Program in Clinical and Animal Reproduction, Universidade Federal Fluminense (UFF), Av. Almirante Ary Parreiras 503, Santa Rosa, Niterói, RJ 24230-340, Brazil. E-mail: alstvet@gmail.com; *Corresponding author: isabellemedvet@gmail.com

${ }^{3}$ Professor, Universidade Federal Fluminense (UFF), Av. Almirante Ary Parreiras 503, Santa Rosa, Niterói, RJ 24230-340, Brazil. E-mails: daniellessa@id.uff.br, vivianmedvet@yahoo.com.br, nayroalencar@id.uff.br, gnsouza@id.uff.br, michelabdalla@id.uff.br

${ }^{4}$ Professor, Universidade Federal Rural do Rio de Janeiro (UFRRJ), BR-465 Km 7, Seropédica, RJ 23897-000, Brazil. E-mail: sauloacaldas@hotmail.com
}

RESUMO.- [Achados clínicos e laboratoriais em ovinos experimentalmente intoxicados por Palicourea marcgravii e o uso do cloreto de magnésio com possível efeito terapêutico na intoxicação.] 0 presente estudo objetivou verificar a eficácia terapêutica do cloreto de magnésio em ovinos intoxicados experimentalmente por Palicourea marcgravii e descrever os achados clínicos e laboratoriais que possam auxiliar no diagnóstico precoce ante mortem dessa intoxicação. P. marcgravii é a principal planta dentro de um grupo de 22 espécies que causam "morte súbita" no Brasil e seu princípio tóxico é o monofluoracetato de sódio. Durante o procedimento, observou-se maior tempo de evolução em 
relação a outros trabalhos utilizando-se a mesma dose da P. marcgravii em ovinos, entretanto todos os animais intoxicados e posteriormente tratados com cloreto de magnésio vieram a óbito. Os ovinos apresentaram sinais clínicos característicos antes da morte, associados a sinais nunca antes descritos nesse tipo de intoxicação, como respiração abdominal, tosse, "head pressing" e nistagmo. Trata-se da primeira avaliação dos parâmetros hematológicos de ovinos intoxicados por P. marcgravi. Foi observado leucocitose com neutrofilia, hiperfibrinogemia e hiperglicemia, associado a elevação dos valores séricos de AST, GLDH, ureia, creatinina, CK, LDH e hipofosfatemia. À necropsia foram notadas alterações como jugular ingurgitada, congestão de grandes vasos, edema pulmonar. Histologicamente havia degeneração hidrópica vacuolar nos túbulos uriníferos contorcidos distais no rim, semelhantes às já relatadas em estudos anteriores, na intoxicação por P. marcgravii.

TERMOS DE INDEXAÇÃO: tratamento, ovinos, intoxicação, Palicourea marcgravii, cloreto de magnésio, diagnóstico, bioquímica sérica, plantas tóxicas.

\section{INTRODUCTION}

In Brazil, 22 plants capable of causing "sudden death" have been described (Nascimento et al. 2018). An important plant of this group is Palicourea marcgravii, (Tokarnia et al. 2012), which has sodium monofluoroacetate (MFA) as the toxic component (Nogueira et al. 2011, Lee et al. 2012). Cattle, (Tokarnia et al. 2012) goats and sheep (Soto-Blanco et al. 2004, Koether et al. 2019) are poisoned naturally.

The clinic-pathological condition is similar in different species of ruminants, wherein they present sudden death without prior clinical signs and absence of changes in necropsy (Tokarnia et al. 2012). They may also show a super acute phase of the disease of up to 72 hours until death (Koether et al. 2019) with characteristic clinical signs, necropsy alterations, and heart failure symptoms, which help in the diagnosis (Tokarnia et al. 1986, 2012, Helayel et al. 2012, Koether et al. 2019).

The treatment of poisoning by MFA and other plants having the same intoxication principle is challenging for physicians and veterinarians (Pessoa et al. 2019). It has been reported that magnesium chloride $\left(\mathrm{MgCl}_{2}\right)$ at a dose of $50 \mathrm{mg} / \mathrm{kg}$ is able to reverse the clinical condition of $90 \%$ of mice poisoned with $15 \mathrm{mg} / \mathrm{kg}$ of MFA (Pereira \& Pereira 2005). Considering this, it is vital to study viable therapies for this type of poisoning in ruminants.

This study aimed to describe the clinical and laboratory findings of sheep experimentally poisoned by P. marcgravii and analyze its treatment using magnesium chloride.

\section{MATERIALS AND METHODS}

This study was approved by the Ethics Committee in the Use of Animals (CEUA) (approval number: 7702030518) and performed at the "Faculdade de Veterinária”, "Universidade Federal Fluminense” (UFF).

Histopathological analyses were performed in the "Setor de Patologia Animal" (SAP) of the "Instituto de Veterinária”, "Universidade Federal Rural do Rio de Janeiro" (UFRRJ). Also, the plant was identified with the code RBR37508 at the "Instituto de Biologia", UFRRJ.
Eight healthy male sheep (Ovis aires) with no defined breed were included in the study. The sheep were of ages 5-12 months and were orally administered $1 \mathrm{~g} / \mathrm{kg}$ of fresh Palicourea marcgravii manually. Considering the proven lethality of the plant in previous studies at the administered dose (Tokarnia et al. 1986, 2012), it was decided to not use a control group with placebo administration for avoiding death and suffering of the animals.

The animals underwent physical examination (Dirksen 1993) and laboratory examination via hemogram and concentrations of plasma fibrinogen (FB) (Jain 1993), serum aspartato aminotransferase (AST), glutamate dehydrogenase (GLDH), gamma-glutamyl transferase (GGT), alkaline phosphatase (ALP), total bilirubin, lactate dehydrogenase (LDH), Creatine kinase (CK), urea, creatinine, glucose, calcium, and phosphorus. These tests were performed using commercial Labtest ${ }^{\circledR}$ kits prior to the administration of $P$. marcgravii (T0). The physical examination was repeated every two hours (T1, T3, and T5) and the hematological and biochemical tests were repeated every four hours (T2 and T4) after the administration of P. marcgravii.

After the onset of clinical signs of poisoning, the sheep were treated with $100 \mathrm{mg} / \mathrm{kg}$ of $\mathrm{MgCl}_{2}$, diluted in $500 \mathrm{~mL}$ of physiological solution, which was administered via intravenous (IV) route at $100 \mathrm{~mL} /$ minute.

The animals that died underwent necropsy, with collection and fixation of organs fragments (heart, lung, kidneys, liver, spleen, diaphragm, intercostal muscle, adrenal, thyroid, and central nervous system) in 10\% buffered formalin solution, which were then routinely processed for histopathology and stained using hematoxylin-eosin (HE) staining for evaluation using an optical microscopy by a single pathologist.

Parametric analyses were performed using student's t-test, with a $5 \%$ significance level. Mean and standard deviation were calculated for all laboratory parameters, in addition to performing physical and complementary examinations. For non-parametric analyses, the Friedman test was used along with the Wilcoxon test for comparing time pairs. The analyses were performed using the Statistical Package for the Social Sciences (IBM SPSS ${ }^{\circledR}$ ) software.

\section{RESULTS AND DISCUSSION}

To the best of our knowledge, this is the first study to demonstrate hematological changes in sheep poisoned by Palicourea marcgravii. This study contributes to a better understanding of the pathophysiology and diagnosis of $P$. marcgravii poisoning, including ante mortem.

Mortality was found to be $100 \%$, indicating ineffectiveness of $\mathrm{MgCl}_{2}$ in the treatment of sheep poisoned by P. marcgravii at the dose and form in which it was administered. These results contradict the $10 \%$ mortality reported by Pereira \& Pereira (2005) in mice. This difference may have occurred because studied P. marcgravii and not sodium monofluorocetate (MFA). It is known that $P$. marcgravii contains other chemical agents that are chemical enhancers of MFA and also because the species of animals used in this study was different for that used in the referenced study, which present distinct metabolic processes (Spinosa et al. 2019).

Clinical and hematological changes were observed before the administration of $\mathrm{MgCl}_{2}$, which confirms that these changes were caused by P. marcgravii and not by $\mathrm{MgCl}_{2}$.

The first clinical signs occurred between $1 \mathrm{~h} 56 \mathrm{~min}$ and $8 \mathrm{~h}$ after administration of the plant, which is similar to that described in prior studies on sheep (Tokarnia et al. 1986, 
Soto-Blanco et al. 2004, Koether et al. 2019). This confirms the toxic potential of the plant used in the study.

All animals showed characteristic clinical signs of $P$. marcgravii poisoning on an average of $12 \mathrm{~h}(23 \mathrm{~min}$ to $24 \mathrm{~h}$ $50 \mathrm{~min}$ ) before death. Similarly, there was a variation in the survival times of sheep ranging from $5 \mathrm{~h} 56 \mathrm{~min}$ to $30 \mathrm{~h} 50$ min after poisoning and 6 min to $24 \mathrm{~h} 25 \mathrm{~min}$ after $\mathrm{MgCl}_{2}$ treatment (Table 1), which are longer than those reported in previous studies where the sheep did not receive treatment for poisoning (Tokarnia et al. 1986, Soto-Blanco et al. 2004). However, a recent study reported survival of up to $72 \mathrm{~h}$ in sheep naturally poisoned with $P$. marcgravii with no treatment (Koether et al. 2019). The longer evolution time enables an important "window" for diagnostic and therapeutic interventions.

The longer survival time may be related to the applied treatment, the fact that MFA decreases the formation of adenosine triphosphate (ATP) in target cells and organs (Durlach \& Bara 2000), and that $\mathrm{MgCl}_{2}$ acts on all reactions involving ATP formation and utilization (Barbagallo et al. 2003). However, the data does not confirm this, as intrinsic and extrinsic factors may interfere with the evolution time (Spinosa et al. 2019). Despite the improvement observed during $\mathrm{MgCl}_{2}$ administration and longer survival time, the animals later presented with worsening of the clinical condition, followed by death in $100 \%$ of those poisoned.

Clinical changes presented by poisoned sheep and their frequencies are listed in Table 2.
Similar changes have been described in other experiments with P. marcgravii in sheep (Tokarnia et al. 1986, Soto-Blanco et al. 2004, Koether et al. 2019). However, abdominal breathing, coughing, head pressing, and nystagmus were never described before in ruminants poisoned by P. marcgravii.

To the best of our knowledge, studies on changes in hemogram, fibrinogen, plasma proteins, and serum biochemistry of sheep poisoned by P. marcgravii are nonexistent in the literature.

The erythrogram and the total plasma protein values remained within the physiological boundaries for the species. In similar works with the bovine species, Serodio et al. (2019) did not observe hemogram changes in the Curraleiro-Pé-Duro and Pantaneiro breeds; however, they described normocytic and normochromic anemia in the nellore breed, an alteration also described by Rodrigues (2015) in crossbred cattle. It is known that the plant has the same mechanism of action on different ruminants (Chenoweth \& Gilman 1946, Barbosa et al. 2003); however, different species have physiological and metabolic peculiarities, and hence react differently to drugs and infectious and toxic agents, among others. These differences have been observed among several breeds within the same species (Serodio et al. 2019, Spinosa et al. 2019).

Increased serum fibrinogen concentrations were observed, which were above physiological parameters, in three sheep $(37.5 \%)$ already in T2, which was also continued in T4. Despite this, significant hyperfibrinogenemia was only identified in T4 $(p<0.05)$ (Table 3). These findings are similar to those described in cattle by Serodio et al. (2019). However, they

Table 1. Time before plant administration and time of plant administration, onset of clinical signs, first hematological changes, time of $\mathrm{MgCl} 2$ administration, evolution, survival after Palicourea marcgravii poisoning and after MgCl2 treatment

\begin{tabular}{|c|c|c|c|c|c|c|c|c|}
\hline Sheep & $\begin{array}{c}\mathrm{T} 0 \\
\text { immediately before } \\
\text { plant administration }\end{array}$ & $\begin{array}{c}\text { Plant } \\
\text { administration } \\
1 \mathrm{~g} / \mathrm{kg} \text { orally }\end{array}$ & $\begin{array}{l}\text { Onset of } \\
\text { clinical } \\
\text { signs }\end{array}$ & $\begin{array}{c}\text { First hematological } \\
\text { changes* }\end{array}$ & $\begin{array}{l}\mathrm{MgCl}_{2} \text { administration } \\
\text { after first clinical and } \\
\text { hematological changes }\end{array}$ & $\begin{array}{l}\text { Evolution } \\
\text { (1st signs } \\
\text { until death) }\end{array}$ & $\begin{array}{l}\text { Survival } \\
\text { after } \\
\text { poisoning }\end{array}$ & $\begin{array}{l}\text { Survival } \\
\text { after } \\
\text { treatment }\end{array}$ \\
\hline 332 & $\begin{array}{l}\text { Without clinical } \\
\text { and hematological } \\
\text { changes }\end{array}$ & $0 \mathrm{~h}$ & $4 \mathrm{~h}$ & From $4 \mathrm{~h}$ & 5 h 16 min & 17 h $07 \mathrm{~min}$ & 21 h 07 min & 11 h 51 min \\
\hline 333 & $\begin{array}{l}\text { Without clinical } \\
\text { and hematological } \\
\text { changes }\end{array}$ & $0 \mathrm{~h}$ & $6 \mathrm{~h}$ & From $4 \mathrm{~h}$ & $25 \mathrm{~min}$ & $24 \mathrm{~h} 50 \mathrm{~min}$ & 30 h 50 min & 24 h 25 min \\
\hline 342 & $\begin{array}{l}\text { Without clinical } \\
\text { and hematological } \\
\text { changes }\end{array}$ & $0 \mathrm{~h}$ & $6 \mathrm{~h}$ & From $4 \mathrm{~h}$ & 2 h 55 min & $10 \mathrm{~h} 02 \mathrm{~min}$ & $16 \mathrm{~h} 02 \mathrm{~min}$ & 7 h 07 min \\
\hline 703 & $\begin{array}{l}\text { Without clinical } \\
\text { and hematological } \\
\text { changes }\end{array}$ & $0 \mathrm{~h}$ & $1 \mathrm{~h} 56 \mathrm{~min}$ & From $4 \mathrm{~h}$ & $3 \mathrm{~h} 15 \mathrm{~min}$ & $4 \mathrm{~h}$ & $5 \mathrm{~h} 56 \mathrm{~min}$ & $45 \mathrm{~min}$ \\
\hline 806 & $\begin{array}{l}\text { Without clinical } \\
\text { and hematological } \\
\text { changes }\end{array}$ & $0 \mathrm{~h}$ & $8 \mathrm{~h}$ & From $4 \mathrm{~h}$ & $17 \mathrm{~min}$ & $23 \mathrm{~min}$ & $08 \mathrm{~h} 23 \mathrm{~min}$ & $6 \mathrm{~min}$ \\
\hline 810 & $\begin{array}{l}\text { Without clinical } \\
\text { and hematological } \\
\text { changes }\end{array}$ & $0 \mathrm{~h}$ & $4 \mathrm{~h}$ & From $4 \mathrm{~h}$ & $46 \mathrm{~min}$ & $5 \mathrm{~h} 04 \mathrm{~min}$ & $9 \mathrm{~h} 04 \mathrm{~min}$ & $4 \mathrm{~h} 18 \mathrm{~min}$ \\
\hline 820 & $\begin{array}{l}\text { Without clinical } \\
\text { and hematological } \\
\text { changes }\end{array}$ & $0 \mathrm{~h}$ & $2 \mathrm{~h}$ & From $4 \mathrm{~h}$ & $2 \mathrm{~h} 47 \mathrm{~min}$ & $8 \mathrm{~h} 17 \mathrm{~min}$ & $10 \mathrm{~h} 17 \mathrm{~min}$ & $5 \mathrm{~h} 30 \mathrm{~min}$ \\
\hline 821 & $\begin{array}{l}\text { Without clinical } \\
\text { and hematological } \\
\text { changes }\end{array}$ & $0 \mathrm{~h}$ & $2 \mathrm{~h} 05 \mathrm{~min}$ & From $4 \mathrm{~h}$ & $3 \mathrm{~h} 50 \mathrm{~min}$ & $4 \mathrm{~h} 25 \mathrm{~min}$ & $6 \mathrm{~h} 30 \mathrm{~min}$ & $35 \mathrm{~min}$ \\
\hline
\end{tabular}

\footnotetext{
* All hematological changes (blood count and serum biochemistry) were observed in the first blood collection after ingestion of the plant (T2 - $4 \mathrm{~h}$ after ingestion of the plant) and their averages remained altered until the death of the animals; Clinical tests carried out according to Dirksen (1993); Hematological tests performed according to Jain (1993) and Kaneko et al. (2008).
} 
were not observed by Rodrigues (2015) who studied the same plant in cattle. Although fibrinogen is considered to be an excellent inflammatory marker for ruminants (Thrall et al. 2015), it is also considered a cardiovascular disease marker and has already been associated with myocardial infarction and sudden death (Bulkley \& Hutchins 1997), which are triggered by $P$. marcgravii poisoning.

Significant leukocytosis $(p<0.05)$ in T2 was observed in global leukometry (Table 3). Studies in cattle poisoned by P. marcgravii did not identify changes in these parameters

Table 2. Absolute frequency of clinical changes observed from the onset of clinical signs until death in relation to the total number of animals

\begin{tabular}{cc}
\hline Clinical changes & Number of animals affected \\
\hline Sternal decubitus & 8 \\
Unrest & 8 \\
Pedal movement & 8 \\
Pollakiuria & 8 \\
Positive venous pulse & 8 \\
Tachycardia & 8 \\
Tachypnea & 8 \\
Pulmonary edema & 7 \\
Tumble & 5 \\
Opistotone & 4 \\
Loss of balance & 4 \\
Movements of digging the ground & 4 \\
Hypochorous mucosa & 3 \\
Cardiac arrhythmia & 2 \\
Auto-auscultation & 2 \\
Bruxism & 2 \\
Apathy & 1 \\
Head pressing & 1 \\
Engorged jugular & 1 \\
Empty chewing movements & 1 \\
Moing & 1 \\
Nystagmus & 1 \\
Abdominal breathing & 1 \\
Cough &
\end{tabular}

(Rodrigues 2015, Serodio et al. 2019). It is possible that these changes were triggered by tissue lesions resulting from the plant's toxic action on various organs, such as kidneys, liver and heart, even before histological visualization.

In specific leukometry, neutrophilia was observed from T2. This occurred in seven (87.5\%) of sheep in T2. Also, in T4, two $(25 \%)$ of sheep presented neutropenia and three (37.5\%) continued to exhibit neutrophilia. However, statistical difference was present only between T0 and T2 $(p<0.05)$ (Table 3). The observed changes suggest responses involved in lesion control (Thrall et al. 2015).

No changes were observed in counts of basophils, eosinophils, lymphocytes, and monocytes, which are similar to those described by Rodrigues (2015) and Serodio et al. (2019) in cattle.

There was an increase in the AST values in seven (87.5\%) sheep (Table 4), similar to that reported by Rodrigues (2015) and Serodio et al. (2019). As the AST values are unspecific, they should be measured and evaluated in combination with other specific enzymes for identifying the lesion's origin (Thrall et al. 2015). The increased AST may be related to cardiac and/ or hepatic injury caused by P. marcgravii.

The GLDH values (Table 4) were increased in six (75\%) sheep and in the overall mean during collection times; however there was no significant difference in the means of different evaluated times $(p>0.05)$. These findings were not found in the existing literature on GLDH dosages in animals of any species poisoned by P. marcgravii. This enzyme has good specificity in herbivores and is directly related to the severity of liver injury (Thrall et al. 2015). Among liver enzymes, the activity of GLDH rises with higher precociousness, followed by AST and GGT (Suttle 1995). This may justify the absence of elevated GGT and ALP. These alterations corroborate the histopathological findings in hepatic fragments of the poisoned sheep and confirm the occurrence of hepatic injury (Thrall et al. 2015).

Progressive increase in serum levels of urea and creatinine was observed in six (75\%) sheep and in the mean times; however, only urea values during $\mathrm{T} 2$ and $\mathrm{T} 4$ rose above the reference indexes for this species (Table 4). In bovine animals, Rodrigues (2015) did not observe any change in these parameters, but Serodio et al. (2019) described elevation of urea and creatinine levels in three groups of animals. Although azotemia was not observed, perhaps due to rapid evolution of the disease and death of the animals, there was an upward

Table 3. Results and means of fibrinogen, global leukometry, and neutrophil values at pre-intoxication (T0) and postintoxication times (T2 and T4) in sheep poisoned by Palicourea marcgravii and treated with $100 \mathrm{mg} / \mathrm{kg} \mathrm{of} \mathrm{MgCl}_{2}$

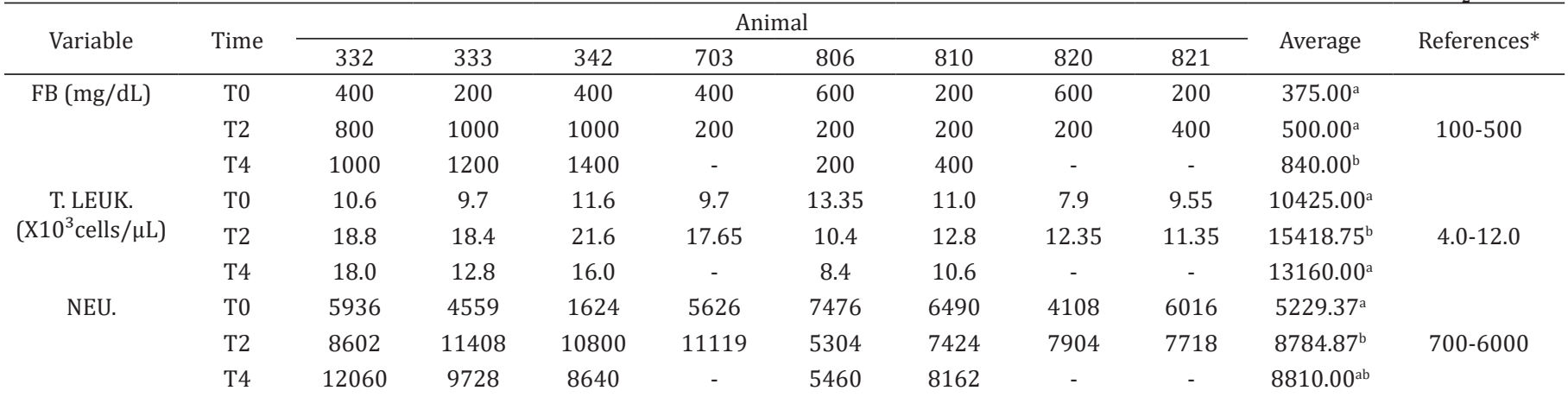

* Jain (1993); FB = plasma fibrinogen, T. LEUK. = total leukocytes, NEU. = neutrophils; ${ }^{\mathrm{a}, \mathrm{b}}$ Different letters between lines signify statistical difference between means obtained using the t-test for paired samples ( $p \leq 0.05)$; $(-)$ signifies death. 
trend in serum urea and creatinine levels, suggesting the onset of renal insufficiency (Thrall et al. 2015). This finding corroborates with the histopathological findings of kidney injury in the poisoned sheep.

Serum concentrations of the enzyme CK (Table 4) increased in the mean times, but without a significant difference $(p>0.05)$, which corroborates with the findings of a study by Serodio et al. (2019) on three groups of bovine animals, as well as with the findings described by Rodrigues (2015). The elevation in serum CK levels suggests the presence of muscle injury in the studied animals, possibly a cardiac lesion, as it is the target organ for this plant's action.

No studies on LDH dosages in animals of any species poisoned by $P$. marcgravii were found in the literature. An increase in serum LDH concentrations (Table 4) was observed in five $(62.5 \%)$ sheep, of which three $(37.5 \%)$ had its increase peak in $\mathrm{T} 2$, slightly decreasing in $\mathrm{T} 4$, with a significant difference $(p<0.05)$ from T0 to T2 and T4. As LDH is a non-specific enzyme, its levels rise due to muscle, hepatic, renal, bone, and pulmonary injuries as well as by abnormal erythrocyte levels (González \& Silva 2006, Thrall et al. 2015). The increase in LDH may have resulted from hepatic, cardiac, and kidney lesions caused by P. marcgravii.

No changes in serum concentrations of bilirubin, ALP, and GGT were observed. An increase in the concentrations of these enzymes was expected (González \& Silva 2006, Thrall et al. 2015) as P. marcgravii causes liver and kidney lesions.

This is the first study wherein calcemia in sheep poisoned by $P$. marcgravii was evaluated. Serum calcium did not show significant changes ( $p>0.05)$, similar to normocalcaemia reported by Helayel et al. (2012) in cattle poisoned naturally by this plant. Animals poisoned by MFA or plants with the same poisoning mechanism tend to present hypocalcemia secondary to serum citrate increase (Collicchio-Zuanaze et al. 2010).

This was the first study that evaluated serum phosphorus of sheep poisoned by P. marcgravii. The mean and individual values of phosphorus (Table 4) were decreased during collection times in all the animals, with a significant difference from T0 to T2 and T4 $(p<0.05)$, as opposed to the findings of Helayel et al. (2012), who reported hyperphosphatemia in cattle poisoned naturally by P. marcgravii. The underlying mechanisms for this are unknown, but the poisoning affected the levels of serum phosphorus, which is a co-factor for energy transfer molecules like ATP, involved in various metabolic pathways of the organism (Reece 2017). It is assumed that because MFA decreases ATP production in the cells of target organs, intracellular phosphorus accumulates to increase ATP production as a feedback. Additionally, citrate accumulation resulting from MFA can interfere with phosphorus metabolism.

Table 4. Individual results and mean of serum hepatic enzymes, serum renal biochemicals, serum muscle enzymes, phosphorus, and glycemia in pre-intoxication (T0) and post-intoxication times (T2 and T4) in sheep poisoned by Palicourea marcgravii and treated with $100 \mathrm{mg} / \mathrm{kg}$ of $\mathrm{MgCl} 2$

\begin{tabular}{|c|c|c|c|c|c|c|c|c|c|c|c|}
\hline \multirow{2}{*}{ Variable } & \multirow{2}{*}{ Time } & \multicolumn{8}{|c|}{ Animal } & \multirow{2}{*}{ Average } & \multirow{2}{*}{ References* } \\
\hline & & 332 & 333 & 342 & 703 & 806 & 810 & 820 & 821 & & \\
\hline \multirow[t]{3}{*}{ AST (U/L) } & T0 & 156 & 182 & 133 & 94 & 184 & 126 & 126 & 113 & $139.3^{\mathrm{a}}$ & $60-280$ \\
\hline & $\mathrm{T} 2$ & 163 & 189 & 148 & 130 & 167 & 151 & 181 & 179 & $163.5^{b}$ & \\
\hline & $\mathrm{T} 4$ & 189 & 237 & 164 & - & 167 & 168 & - & - & $185.0^{\mathrm{b}}$ & \\
\hline \multirow[t]{3}{*}{ GLDH (mg/dL) } & T0 & 11 & 12 & 34 & 15 & 20 & 10 & 7 & 5 & $14.3^{\mathrm{a}}$ & $31^{* * *}$ \\
\hline & $\mathrm{T} 2$ & 13 & 13 & 30 & 16 & 12 & 14 & 13 & 8 & $14.9^{\mathrm{a}}$ & \\
\hline & $\mathrm{T} 4$ & 14 & 24 & 29 & - & 12 & 18 & - & - & $19.4^{\mathrm{a}}$ & \\
\hline \multirow[t]{3}{*}{ Creatinine (mg/dL) } & T0 & 0.59 & 0.74 & 0.7 & 0.65 & 0.85 & 0.82 & 0.77 & 0.89 & $0.751^{\mathrm{a}}$ & $1.2-1.9$ \\
\hline & $\mathrm{T} 2$ & 0.66 & 0.7 & 0.66 & 0.74 & 1.17 & 1.06 & 0.93 & 0.99 & $0.864^{\mathrm{b}}$ & \\
\hline & $\mathrm{T} 4$ & 0.67 & 0.69 & 0.73 & - & 1.22 & 0.93 & - & - & $0.848^{\mathrm{ab}}$ & \\
\hline \multirow[t]{3}{*}{ Urea (mg/dL) } & T0 & 24 & 31 & 40 & 21 & 33 & 14 & 33 & 34 & $28.8^{a}$ & $17.12-42.8$ \\
\hline & $\mathrm{T} 2$ & 44 & 41 & 39 & 47 & 62 & 50 & 56 & 57 & $49.5^{b}$ & \\
\hline & $\mathrm{T} 4$ & 42 & 44 & 31 & - & 75 & 51 & - & - & $48.6^{\mathrm{a}}$ & \\
\hline \multirow[t]{3}{*}{$\mathrm{CK}(\mathrm{U} / \mathrm{L})$} & T0 & 209 & 217 & 145 & 255 & $2371^{* *}$ & 180 & 232 & 469 & $509.7^{\mathrm{a}}$ & $8.1-12.9$ \\
\hline & $\mathrm{T} 2$ & 691 & 784 & 776 & 863 & 794 & 831 & 1195 & 1580 & $939.2^{\mathrm{ab}}$ & \\
\hline & $\mathrm{T} 4$ & 901 & 1469 & 893 & - & 980 & 881 & - & - & $1024.8^{\mathrm{a}}$ & \\
\hline \multirow[t]{3}{*}{ LDH (U/L) } & T0 & 1114 & 1201 & 959 & 850 & 1413 & 809 & 792 & 749 & $985.9^{a}$ & $238-440$ \\
\hline & $\mathrm{T} 2$ & 1446 & 1467 & 1273 & 1386 & 1455 & 1341 & 1626 & 1629 & $1452.9^{\mathrm{b}}$ & \\
\hline & $\mathrm{T} 4$ & 1533 & 1679 & 1256 & - & 1311 & 1235 & - & - & $1402.8^{\mathrm{b}}$ & \\
\hline \multirow[t]{3}{*}{ Phosphorus (mg/dL) } & T0 & 10.29 & 10.43 & 7.08 & 8.08 & 10.82 & 8.51 & 9.9 & 8.42 & $9.191^{b}$ & $5.0-7.3$ \\
\hline & $\mathrm{T} 2$ & 10.5 & 9.84 & 6.25 & 6.86 & 10.25 & 7.11 & 9.5 & 7.11 & $8.428^{\mathrm{a}}$ & \\
\hline & $\mathrm{T} 4$ & 6.41 & 8.57 & 5.13 & - & 9.39 & 6.86 & - & - & $7.272^{\mathrm{a}}$ & \\
\hline \multirow[t]{3}{*}{ Blood glucose (mg/dL) } & T0 & 78 & 70 & 109 & 92 & 93 & 82 & 79 & 145 & $93.5^{\mathrm{a}}$ & $50-80$ \\
\hline & $\mathrm{T} 2$ & 78 & 94 & 81 & 101 & 90 & 145 & 96 & 73 & $94.8^{\mathrm{a}}$ & \\
\hline & $\mathrm{T} 4$ & 90 & 124 & 157 & - & 65 & 187 & - & - & $124.6^{\mathrm{a}}$ & \\
\hline
\end{tabular}

* Kaneko et al. (2008), ${ }^{* *}$ hemolysed sample, ${ }^{* * *}$ reference value for cattle, no references for sheep were found in the literature; AST = serum aspartato aminotransferase, GLDH = glutamate dehydrogenase, $\mathrm{CK}=$ creatine kinase, $\mathrm{LDH}=$ lactate dehydrogenase; ${ }^{\mathrm{a}, \mathrm{b}}$ Different letters between lines signify statistical difference between the means obtained using t-test for paired samples $(p \leq 0.05)$; $(-)$ signifies death. 
Hyperglycemia was observed during T2 in six (75\%) sheep and during T4 in four (50\%) sheep. Although the values were above reference indexes, a significant difference was not observed between the evaluated times $(p>0.05)$ (Table 4$)$. Hyperglycemia with no significant difference between the groups was also observed by Serodio et al. (2019) in a study on cattle, unlike Rodrigues (2015), whose evaluated means remained within the normal range. These findings can be justified by the increased demand of glucose and glycogen as an energy source for anaerobic metabolism and increased endogenous cortisol, which common findings of MFA poisoning (Marrazzi \& Holliday 1981). However, situations of stress can cause hyperglycemia in different ruminant species (Petersen et al. 2004, Radostits et al. 2007).

Necropsy revealed changes associated with heart failure, such as engorged jugular, large vessel congestion, pulmonary edema, and foamy fluid in the trachea region, in addition to the presence of blood, pericardial fluid, edema adjacent to the gallbladder, and liver with rounded edges. Histopathological examination revealed slight vacuolar hydropic degeneration in the distal twisted uriniferous tubules in the kidney and in the liver, a slight to moderate edema in the space of Disse, discreet to prominent vacuolization of hepatocytes in the centrilobular region associated with hepatocyte swelling, and discreet paracentral coagulation necrosis. In the myocardium, there were some areas, and foci of coagulative necrosis, characterized by cytoplasm increase in muscle fibers and pycnosis/caryorrexia and/or nuclei disappearance. These findings were similar to those described in previous studies on sheep poisoned by P. marcgravii, which were not treated with $\mathrm{MgCl}_{2}$ (Tokarnia et al. 1986, Soto-Blanco et al. 2004, Koether et al. 2019). These alterations explain the changes observed in the leukometry, fibrinogen concentration, and serum biochemistry.

\section{CONCLUSIONS}

The study suggests that some sheep poisoned by Palicourea marcgravii present clinical signs prior to death, which aids diagnostic and therapeutic procedures. In addition to the clinical signs already described in sheep poisoned by $P$. marcgravii, the sheep may present with abdominal breathing, cough, head pressing, and nystagmus, which are signs that have not been described before.

The most important laboratory changes are leukocytosis, variable results of neutrophils, hyperglycemia, hypophosphatemia, and elevation of serum AST, GLDH, CK, LDH, urea, and creatinine.

Histological changes are necessary for confirmation of the diagnosis.

Also, $\mathrm{MgCl}_{2}$ did not have a therapeutic effect (according to the performed protocol) on P. marcgravii poisoning in sheep.

The findings may aid the early ante mortem diagnosis of this type of poisoning and corroborate in the development of therapeutic protocols.

Acknowledgements.- We are grateful for the financial support obtained from the "Coordenação de Aperfeiçoamento de Pessoal de Nível Superior" (CAPES). The authors thank Crimson Interactive Pvt. Ltd. (Ulatus) $<$ http://www.ulatus.com.br> for the assistance in manuscript translation and editing.

Conflict of interest statement.- The authors have no competing interests.

\section{REFERENCES}

Barbagallo M., Dominguez L.J., Galioto A., Ferlisi A., Cani C., Malfa L., Pineo A., Busardo A. \& Paolisso G. 2003. Role of magnesium in insulin action, diabetes and cardio-metabolic syndrome X. Mol. Asp. Med. 24(1/3):39-52. <https://dx.doi.org/10.1016/S0098-2997(02)00090-0><PMid:12537988>

Barbosa J.D., Oliveira C.M.C., Tokarnia C.H. \& Riet-Correa F. 2003. Comparação da sensibilidade de bovinos e búfalos à intoxicação por Palicourea marcgravii (Rubiaceae). Pesq. Vet. Bras. 23(4):167-172.<https://dx.doi.org/10.1590/ S0100-736X2003000400005>

Bulkley B.H. \& Hutchins G.M. 1997. Myocardial consequences of coronary artery bypass graft surgery: the paradox of necrosis in areas of revascularization. Circulation 56(6):906-913. <https://dx.doi.org/10.1161/01.CIR.56.6.906> $<$ PMid:303553>

Chenoweth M.B. \& Gilman A. 1946. Pharmacological studies on fluoroacetate I: responses of species to fluoroacetate. J. Pharmacol. Exp. 87:90-103. <PMid:20989221>

Collicchio-Zuanaze R.C., Sakate M., Langrafe L., Takahira R.K. \& Burini C. 2010. Hematological and biochemical profiles and histopathological evaluation of experimental intoxication by sodium fluoroacetate in cats. Human Exp. Toxicol. 29(11):903-913.<https://dx.doi.org/10.1177/0960327110362908> <PMid:20354062>

Dirksen G. 1993. Sistema digestivo, p.166-240. In: Gründer H. \& Stöber M. (Eds), Rosemberger - Exame Clínico dos Bovinos. 3aㅡ ed. Guanabara Koogan, Rio de Janeiro.

Durlach J. \& Bara M. 2000. Le Magnesium en Biologie et en Médecine. $2^{\text {a }}$ ed. Editions International Medicals, Cachan, p.19-66.

González F.H.D. \& Silva S.C. 2006. Introdução à Bioquímica Clínica Veterinária. 2 ${ }^{\mathrm{a}}$ ed. Editora da Universidade Federal do Rio Grande do Sul, Porto Alegre. 358p.

Helayel M.A., Barbosa F.B., Carvalho Júnior C.P., Ramos A.T., Aguiar Junior M.A., Aguiar D.M.C., Bruns L.V. \& Silva M.A.G. 2012. Natural poisoning by Palicourea marcgravii (Rubiaceae) in cattle in the State of Tocantins. Arq. Pesq. Anim. 1(1):8-12.

Jain N.C. 1993. Essentials of Veterinary Hematology. Lea and Febiger, Philadelphia. 1221p.

Kaneko J.J., Harvey J.W. \& Bruss M.L. 2008. Carbohydrate metabolism and its deseases, p.45-115. In: Kaneko J.J., Harvey J.W. \& Bruss M.L. (Eds), Clinical Biochemistry of Domestic Animals. $6^{a}$ ed. Academic Press, San Diego.

Koether K., Lee S.T., Belluci R.S., Garcia R., Pfister J.A., Cunha P.H.J., Rocha N.S., Borges A.S. \& Oliveira-Filho J.P. 2019. Spontaneous poisoning by Palicourea marcgravii (Rubiaceae) in a sheep herd in southeastern Brazil. Toxicon 161:1-3. <https://dx.doi.org/10.1016/j.toxicon.2019.02.015>

Lee S.T., Cook D., Riet-Correa F., Pfister J.A., Anderson W.R., Lima F.G. \& Gardner D.R. 2012. Detection of monofluoroacetate in Palicourea and Amorimia species. Toxicon 60(5):791-796. <https://dx.doi.org/10.1016/j. toxicon.2012.05.029><PMid:22699106>

Marrazzi M.A. \& Holliday J.F. 1981. Comparison of hypoglycemia-induced insulin and fluoroacetate-induced convulsions in gold thioglucose lesioned mice. Biochem. Pharmacol. 30(23):3231-3237. <https://dx.doi. org/10.1016/0006-2952(81)90523-2> <PMid:6797439>

Nascimento N.C.F., Aires L.D.A., Pfister J.A., Medeiros R.M., Riet-Correa F. \& Mendonça F.S. 2018. Cardiotoxic plants affecting ruminants in Brazil. Pesq. Vet. Bras. 38(7):1239-1249. <https://dx.doi.org/10.1590/16785150-pvb-5548>

Nogueira V.A., Peixoto T.C., França T.N., Caldas S.A. \& Peixoto P.V. 2011. Intoxicação por monoluoroacetato em animais. Pesq. Vet. Bras. 31(10):823838. <https://dx.doi.org/10.1590/S0100-736X2011001000001>

Pereira N.A. \& Pereira S.M.N. 2005. Contribuição ao estudo de plantas tóxicas e seus antagonistas: erva-de-rato, Rubiaceae, Palicourea marcgravii, St. Hil. Revta Bras. Farmácia, Rio de Janeiro, 86(3):109-111. 
Pessoa D.A.N., Medeiros R.M.T. \& Riet-Correa F. 2019. Techniques for prevention and control of poisoning by sodium monofluoroacetate (MFA)-containing plants in ruminants. Pesq. Vet. Bras. 39(10):771-779. <https://dx.doi. org/10.1590/1678-5150-pvb-6373>

Petersen H.H., Nielsen J.P. \& Heegaard P.M.H. 2004. Application of acute phase protein measurements in veterinary clinical chemistry. Vet. Res. 35(2):163187. <https://dx.doi.org/10.1051/vetres:2004002> <PMid:15099494>

Radostits O.M., Gay C.C., Hinchcliff K.W. \& Constable P.D. 2007. Veterinary Medicine: a textbook of the disorders of cattle, horses, sheep, pigs, and goats. 10th ed. Saunders Elsevier, Philadelphia, p.1613-1680.

Reece W.0. 2017. Dukes - Fisiologia de Animais Domésticos. 13ª ed. Guanabara Koogan, Rio de Janeiro, p.1257-1260.

Rodrigues M.K.F. 2015. Tratamento com tiossulfato de sódio em bovinos intoxicados experimentalmente pela Palicourea marcgravii A. St. Hil. Master's Thesis in Animal Science, Escola de Veterinária e Zootecnia, Universidade Federal de Goiás, Goiânia. 70p.

Serodio J.J., Castro L.T.S., Morais T.L., Cunha R.D.S., Sant'Ana F.J.F., Juliano R.S., Borges J.R.J., Fioravanti M.C.S. \& Cunha P.H.J. 2019. Evaluation of the resistance of Nellore, Curraleiro-Pé-Duro and Pantaneiro cattle breeds by experimental intoxication of Palicourea marcgravii. Toxicon 168:126-130. <https://dx.doi.org/10.1016/j.toxicon.2019.07.008><PMid:31325459>

Soto-Blanco B., Haraguchi M., Silva J.A. \& Górniak S.L. 2004. Natural intoxication of goats and sheep by Palicourea marcgravii St. Hil. (Rubiaceae). Revta Caatinga 17(1):52-56.

Spinosa H.S., Górniak S.L. \& Palermo-Neto J. 2019. Toxicologia aplicada à medicina veterinária. $2^{\mathrm{a}}$ ed. Manole, São Paulo. 560p.

Suttle N.F. 1995. Cooper poisoning in ruminants. Moredun Foundation News Sheet 2(7):1-6.

Thrall M.A., Weiser G., Allison R.W. \& Campbell T.W. 2015. Avaliação laboratorial das proteínas do plasma e do soro sanguíneo, p.978-1001. In: Fagliari J.F. \& Thiesen R. (Eds), Hematologia e Bioquímica Clínica Veterinária. 2a ed. Editora Roca, São Paulo.

Tokarnia C.H., Brito M.F., Barbosa J.D., Peixoto P.V. \& Döbereiner J. 2012. Plantas que afetam o funcionamento do coração, p.27-94. In: Ibid. (Eds), Plantas Tóxicas do Brasil para Animais de Produção. 2a ed. Helianthus, Rio de Janeiro.

Tokarnia C.H., Peixoto P.V. \& Döbereiner J. 1986. Experimental poisoning by Palicourea marcgravii (Rubiaceae) in sheep. Pesq. Vet. Bras. 6(4):121-131. 